\title{
NOTES ON MALESIAN FABACEAE (LEGUMINOSAE-PAPILIONOIDEAE) 9. The genus Paraderris
}

\author{
FRITS ADEMA \\ Nationaal Herbarium Nederland, Universiteit Leiden branch, \\ P.O. Box 9514, 2300 RA Leiden, The Netherlands
}

\begin{abstract}
SUMMARY
The genus Paraderris (Miq.) Geesink is discussed, mainly for the Malesian area. Two new species, P. luzoniense and P. ornithocephalus are described. A key to the Malesian species is given. All currently recognized species are enumerated. All obligatory new combinations have been made.
\end{abstract}

Key words: Paraderris, new species, new combinations, checklist, Malesia.

\section{INTRODUCTION}

Paraderris (Miq.) Geesink is a small genus of papilionoid Leguminosae belonging to the tribe Millettieae (Tephrosieae) (Geesink, 1981, 1984). The genus consists of c. 15 species. It is distributed through much of SE Asia from N India to S China and through Indochina, Thailand, Malesia to New Guinea.

Paraderris is closely related to Derris Lour. and was formerly included in that genus as a section (Bentham, 1860; Thothathri, 1961, 1982). However, I have showed that Geesink (1984) was right in separating Paraderris from Derris (Adema, 2001). The genus Paraderris is most easily characterized by its inflorescences: pseudoracemes (or pseudopanicles) with slender brachyblasts with usually three flowers at the apex, each flower supported by one bract and two bracteoles (Fig. 1). Derris has knob-like to slender brachyblasts with 3-15 or more flowers usually scattered over the brachyblasts. Furthermore Paraderris usually has hairy anthers and often a row of hairs along the lower suture at the innerside of the ovary. The three characters mentioned above together with a few others form a unique set of characters. Morphologically Paraderris clearly forms a monophyletic group (Adema, 2001).

Paraderris can rather easily be divided into two informal groups of species using only the amount of hairs on several organs as a character:

\section{PARADERRIS CUNEIFOLIA-GROUP}

Leaflets above and below glabrous to thinly strigose. Calyx outside glabrous or with some scattered hairs, margin of teeth ciliate. Standard usually glabrous.

The central species is $P$. cuneifolia. Furthermore $P$. canarensis, $P$. hainanensis, P. laotica, P. lianoides (Fig. 2a-c), P. montana (Fig. $2 \mathrm{~g}-\mathrm{j}$ ) belong to this group. 


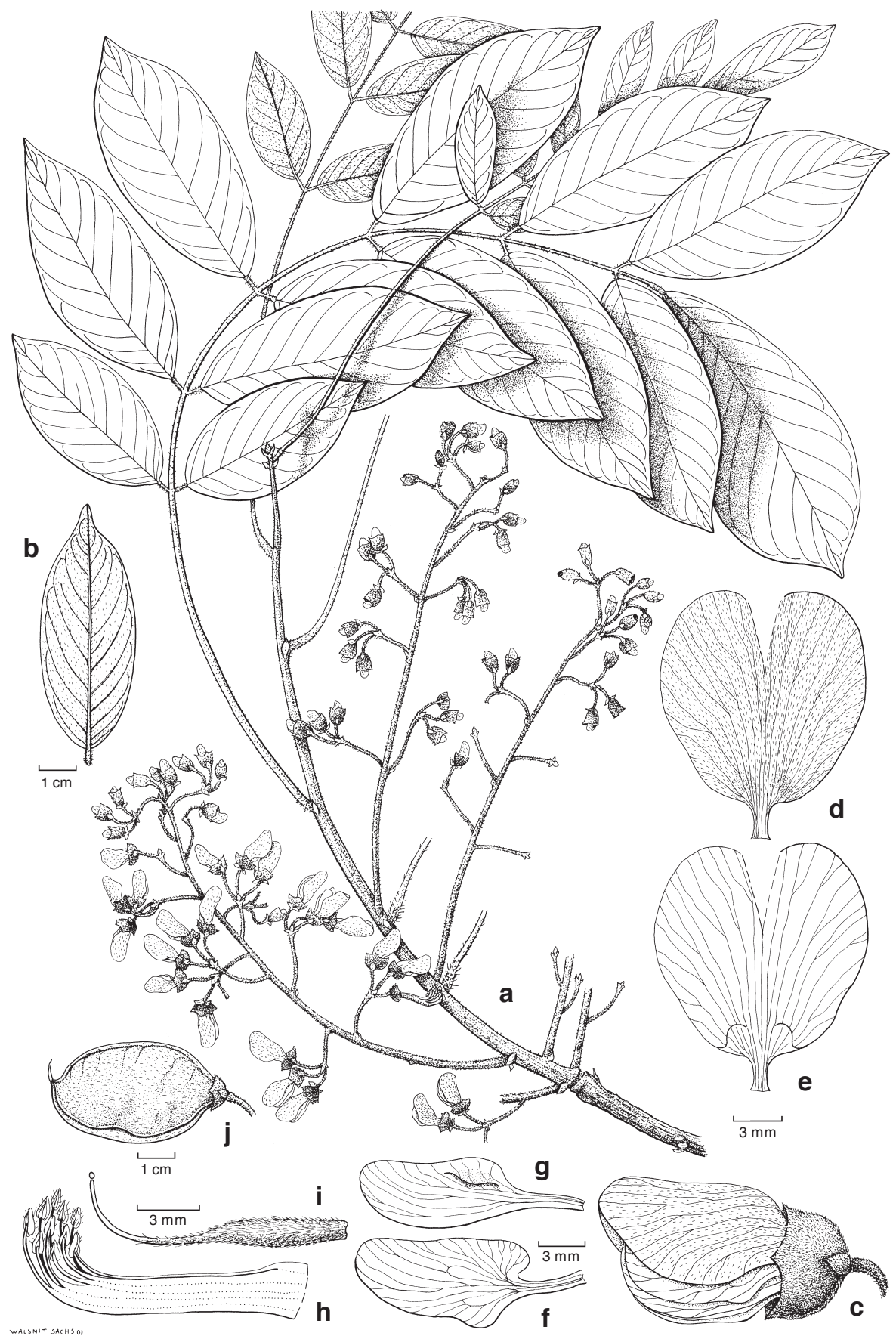

Fig. 1. Paraderris elliptica (Wall.) Adema. a. Habit; b. leaflet from below; c. flower; d. standard from outside; e. standard from inside; f. wing petal; g. keel petal; h. stamens; i. pistil; j. pod (a-i: Kornassi 495; j: Stone et al. 15190). 
There has been much confusion in this group about some of the species and their names. A rather large number of species has been described on either flowering or fruiting specimens alone and only recently the different parts have been brought together. However, even after that, it has remained uncertain what belongs to P. cuneifolia, especially because at least one species of this group has been cultivated and selections (cultons, cultivars) do exist. Various, quite different, specimens have been included in $P$. cuneifolia, whereas others have been kept apart as separate species. For the Flora Malesiana area the relationship between Paraderris cuneifolia,Derris malaccensis and $D$. montana needs to be clarified. The differences between D. malaccensis and D. montana are very slight and in my opinion insufficient to keep the two separate. As montana is the older epithet I have united the two under that name in Paraderris as P. montana. The differences between $P$. cuneifolia and P. montana are small but constant and in my opinion sufficient to keep the two species separate (Table 1). Paraderris cuneifolia is a northern taxon, P. montana a southern one.

Paraderris cuneifolia: Leaflets rather small, 1-10 by $0.5-5 \mathrm{~cm}$, base cuneate, apex rounded to short-acuminate, acumen 3-4 mm long. Calyx 3.5-4.5 mm long.

Distribution - N India, Nepal, Burma, S China, N Thailand.

Paraderris montana: Leaflets larger, $5-17$ by $2.5-9 \mathrm{~cm}$, base rounded (rarely cuneate), apex acuminate, acumen 5-20 mm long. Calyx 4-9 mm long.

Distribution - Thailand, throughout Malesia.

Several Philippine specimens are quite different in fruit from P. cuneifolia and P. montana. The Philippine plants have flattened fruits with wings along both sutures, whereas $P$. cuneifolia has thicker fruits, usually with only a wing along the upper suture, rarely with also a narrow wing along the lower suture. Paraderris montana usually has thick fruits either without wings or winged along the upper suture only, or, rarely, winged along both sutures (Table 1). For the Philippine plants the old name Derris lianoides Elmer, which becomes Paraderris lianoides (Elmer) Adema, has been revived.

Table 1. Differences between Paraderris cuneifolia (Benth.) Geesink, P. lianoides (Elmer) Adema and P. montana (Benth.) Adema.

\begin{tabular}{|c|c|c|c|}
\hline & cuneifolia & lianoides & montana \\
\hline leaflets, size $(\mathrm{cm})$ & $1-10$ by $0.5-5$ & $6-11$ by $1.5-5.5$ & $5-17$ by $2.5-9$ \\
\hline base of leaflets & usually cuneate & $\begin{array}{l}\text { rounded } \\
\text { cuneate }\end{array}$ & rounded, rarely \\
\hline length acumen (mm) & $1-4$ & $4-11$ & $5-20$ \\
\hline width upper wing of fruit (mm) & $1-3$ & $2-5$ & $0-2(-4)$ \\
\hline width lower wing of fruit (mm) & $0-1(-2)$ & $2-3$ & $0-1(-2)$ \\
\hline length of pedicels (mm) & $3-4.5$ & $4-8$ & $4-9$ \\
\hline blade of standard (mm) & $9-10$ by 9 & $10.5-15$ by $9-12$ & $10-17$ by $8-20$ \\
\hline blade of wings (mm) & $7-8$ by 3 & $8-12$ by $3-4$ & $8-13$ by $2.5-6$ \\
\hline blade of keel petals (mm) & $7-7.5$ by $3-3.5$ & $7.5-11$ by $3.5-5$ & $8-12$ by $3-6$ \\
\hline pod, size $(\mathrm{cm})$ & $\begin{array}{l}2-5 \text { by } 1.5-2.5 \\
\text { by } 0.7-0.9\end{array}$ & $\begin{array}{l}4-10.5 \text { by } 1.5-2.5 \\
\text { by? }\end{array}$ & $\begin{array}{l}2-9.5 \text { by } 2-3.2 \\
\text { by } 0.5-1.4\end{array}$ \\
\hline
\end{tabular}



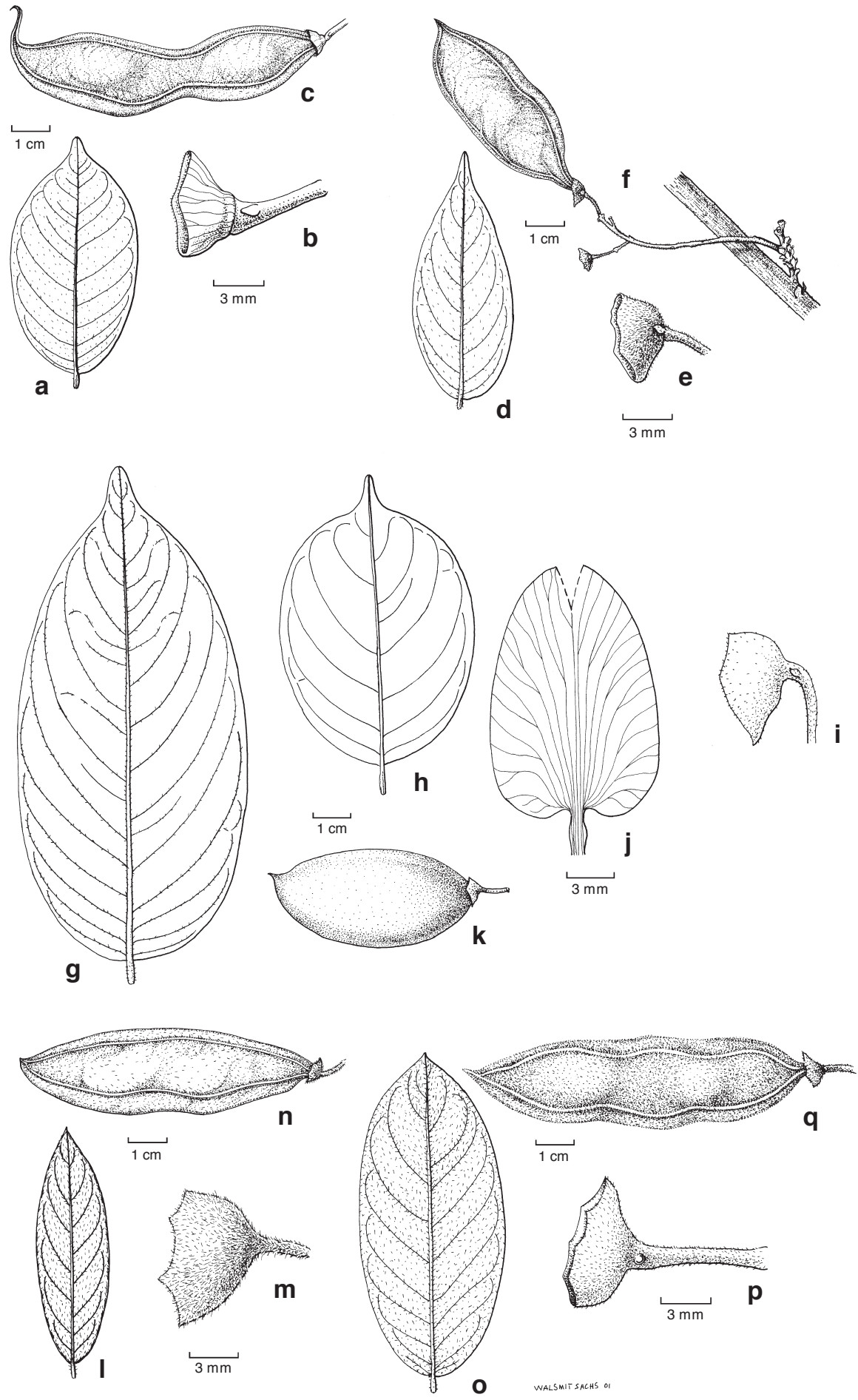


\section{PARADERRIS ELLIPTICA-GROUP}

Leaflets above glabrous to thinly sericeous, below (thinly) sericeous. Calyx outside sericeous. Standard outside sericeous (Fig. 1).

The central species is P. elliptica. Furthermore P. lacei, P. lushaiensis, P. luzoniensis (Fig. 2d-f), P. oblongifolia (Fig. 21-n), P. ornithocephala (Fig. 3), P.piscatoria (Fig. $2 \mathrm{o}-\mathrm{q}$ ) belong to this group.

Also in this group there has been much confusion about the delimitation of the taxa. Much of this confusion originated with the drawing which accompanies the original description of Pongamia elliptica by Wallich (1832). This drawing seems to indicate that the pod has two wings. However, the description indicates one wing only. Fruiting specimens in the original material and other pod bearing plants associated with these specimens (cultivated in Calcutta and collected at or about the same time as the Wallich specimens) all have only one wing along the upper suture. Fruiting specimens from the Philippines have pods with two wide wings. The flowering specimens accompanying these fruiting ones are often very similar to flowering specimens of Paraderris elliptica. The leaves indicate that there are two sets of plants in the Philippines: one with rather narrow leaflets, the other with wider leaflets similar to those of P. elliptica. The first group also has often smaller flowers (Table 2). For the Philippine taxa two older names have been revived: Derris oblongifolia Merr. as Paraderris oblongifolia (Merr.) Adema and Cyclista piscatoria Blanco as Paraderris piscatoria (Blanco) Adema.

Table 2. Differences between Paraderris elliptica (Wall.) Adema, P. oblongifolia (Merr.) Adema and P. piscatoria (Blanco) Adema.

\begin{tabular}{llll}
\hline & elliptica & oblongifolia & piscatoria \\
\hline terminal leaflets $(\mathrm{cm})$ & $9-16.5$ by $2-5$ & $2-7.5$ by $0.5-2$ & $4.5-14$ by $2-7$ \\
bracts to the brachyblasts $(\mathrm{mm})$ & $2-3.5$ by $1.5-2$ & 0.9 by 0.8 & 1.9 by 2.4 \\
bracts to the flowers $(\mathrm{mm})$ & $1.6-3.5$ by $1-1.9$ & $0.8-0.9$ by 0.6 & $1.2-2$ by $1-1.6$ \\
calyx length $(\mathrm{mm})$ & $6-9$ & $4-6$ & $6-7$ \\
blade of standard (mm) & $12-18$ by $10-16$ & $13-14$ by $10-12$ & $15-18$ by $14-20$ \\
blade of wings $(\mathrm{mm})$ & $10-13$ by $5-7$ & $10-11.5$ by 4 & 12 by $5-6$ \\
anther size $(\mathrm{mm})$ & $1.2-1.6$ by $0.5-1$ & $1-1.3$ by $0.4-0.6$ & $1.1-1.8$ by 0.7 \\
width upper wing of fruit $(\mathrm{mm})$ & $1.5-2.1$ & $2-6$ & $2-5$ \\
width lower wing of fruit $(\mathrm{mm})$ & - & $1-3$ & $(1-) 3-4$ \\
\hline
\end{tabular}

Fig. 2. Paraderris (Miq.) Geesink. Details of various species. - a-c: P. lianoides (Elmer) Adema. a. Terminal leaflet; b. calyx; c. pod. - d-f: P. luzoniensis Adema. d. Terminal leaflet; e. calyx; f. infructescence and pod. - g-k: P. montana (Benth.) Adema. g, h. Terminal leaflets; i. calyx; j. standard from outside; k. pod. - 1-n: P. oblongifolia (Merr.) Adema. 1. Terminal leaflet; m. calyx; n. pod. - o-q: P. piscatoria (Blanco) Adema. o. Terminal leaflet; p. calyx; q. pod (a-c: SMHI 1863; d-f: Ridsdale et al. ISU 564; g: Blume s.n. (L 908.114-2552); h, k: De Wilde \& De Wilde-Duyfjes 21227; i, j: BNBFD A2809; 1, n: Elmer 11075; m: Elmer 15528; o-q: Merrill Spec. Blanc. 469). 


\section{NEW SPECIES}

Among the specimens that do not fit the descriptions of known species of Paraderris two clearly represent undescribed species. One, Ridsdale et al. 194564, from Luzon, the Philippines, differs especially in its leaflets; the other one, Dransfield et al. 7554 from Kepala Burung, Papua, Indonesia, differs in first view by its fruits. These specimens are described below as new species.

Paraderris luzoniensis Adema, spec. nov. - Fig. 2d-f

In aspectibus aliquot $P$. piscatoriae similis qua differt in foliis: in $P$. luzoniense ovata ad elliptica vel anguste obovata, ratione longitudinis/latitudinis (2.5-)3-4.8, infra albe glauca, in P.piscatoria elliptica ad obovata, ratione longitudinis/latitudinis $1.5-3$, infra viride. In P. luzoniense folia inflorescentia plerumque in brachyblastis inserta, in P. piscatoria folia inflorescentiae plerumque in dolichoblastis. - Typus: Ridsdale et al. ISU 564 (holo L; iso K), Philippines, Luzon, Palanan area, Dimpnat, 15.4.1992.

Liana. Twigs terete, strigose, c. $6 \mathrm{~mm}$ diam. Stipules obliquely triangular, 1.5 by $2 \mathrm{~mm}$, outside sericeous, inside glabrous. Leaves with 11 leaflets. Petiole 6-7.5 cm long, striate, thinly strigose; rachis $7.5-8.5 \mathrm{~cm}$ long, as the petiole; pulvinus $6 \mathrm{~mm}$ long. Leaflets: terminal narrowly obovate, $7-10.5$ by $1.5-2.5 \mathrm{~cm}$, index $4.3-4.4$, base cuneate, apex acuminate, acumen 6-10 mm long, above with very few widely scattered hairs, below thinly strigose, whitish glaucous by papillae, midrib sunken above, nerves flat above, 7-10 per side, 4-12 mm apart, nervation reticulate; lateral mostly as the terminal, \pm ovate to elliptic, $4-11.5$ by $1-2.5 \mathrm{~cm}$, index (2.5-)3-4.8; pulvinus $4-7 \mathrm{~mm}$ long. Inflorescences on short shoots, axillary or terminal, pseudoracemes. Brachyblasts slender, 3-flowered at apex. Calyx in fruit thinly sericeous outside. Pods flattened, broadly strap-like, green, $5.5-8.5$ by $2 \mathrm{~cm}$, upper wing $2-3 \mathrm{~mm}$ wide, lower wing $1 \mathrm{~mm}$ wide, valves thinly strigose, base and apex slightly hairy.

Distribution - Philippines, Luzon.

Habitat \& Ecology - Secondary forest on riverine gravel banks surrounded by ultrabasics. Altitude $50 \mathrm{~m}$. Fruiting: April.

Note - Quite different from all other Paraderris species in its leaves. The other Philippine species all have wider leaflets that are not as glaucous below as the new species.

Paraderris ornithocephala Adema, spec. nov. - Fig. 3

In aspectibus aliquot gregis $P$. ellipticae speciebus similis. A P. elliptica in leguminibus 2-alatis differt. A P. piscatoriae in foliolorum numero differt 9 in P. ornithocephala, 9-17 in P. piscatoria, foliolorum lateris superioris indumentum: in P. ornithocephala glaber, in $P$. piscatoria fere glaber ad rare sericeus, et in leguminibus: in $P$. ornithocephala discoidea ad ellipsoidea $2.5-5.5$ by $2.5-3.5 \mathrm{~cm}$ glauca, in P. piscatoria late lorata $4.5-11$ by $1.5-4$ cm non glauca. - Typus: Dransfield et al. 7554 (holo K; iso L), Papua, NE Kepala Burung, Manokwari, Numi, Sungai Asai, 15.8.1995.

Liana. Twigs pendulous, terete, hollow, 8-12 mm diam., sericeous when young, soon glabrous. Bark rather rough and flaky. Leaves with 9 leaflets. Petiole $6.5-7 \mathrm{~cm}$ long, striate, grooved above, thinly hirsute; rachis as the petiole, $4.5-9.5 \mathrm{~cm}$ long; pulvinus $8-10 \mathrm{~mm}$ long. Leaflets: terminal narrowly obovate, c. 14.2 by $5.3 \mathrm{~cm}$, index 2.6, base 


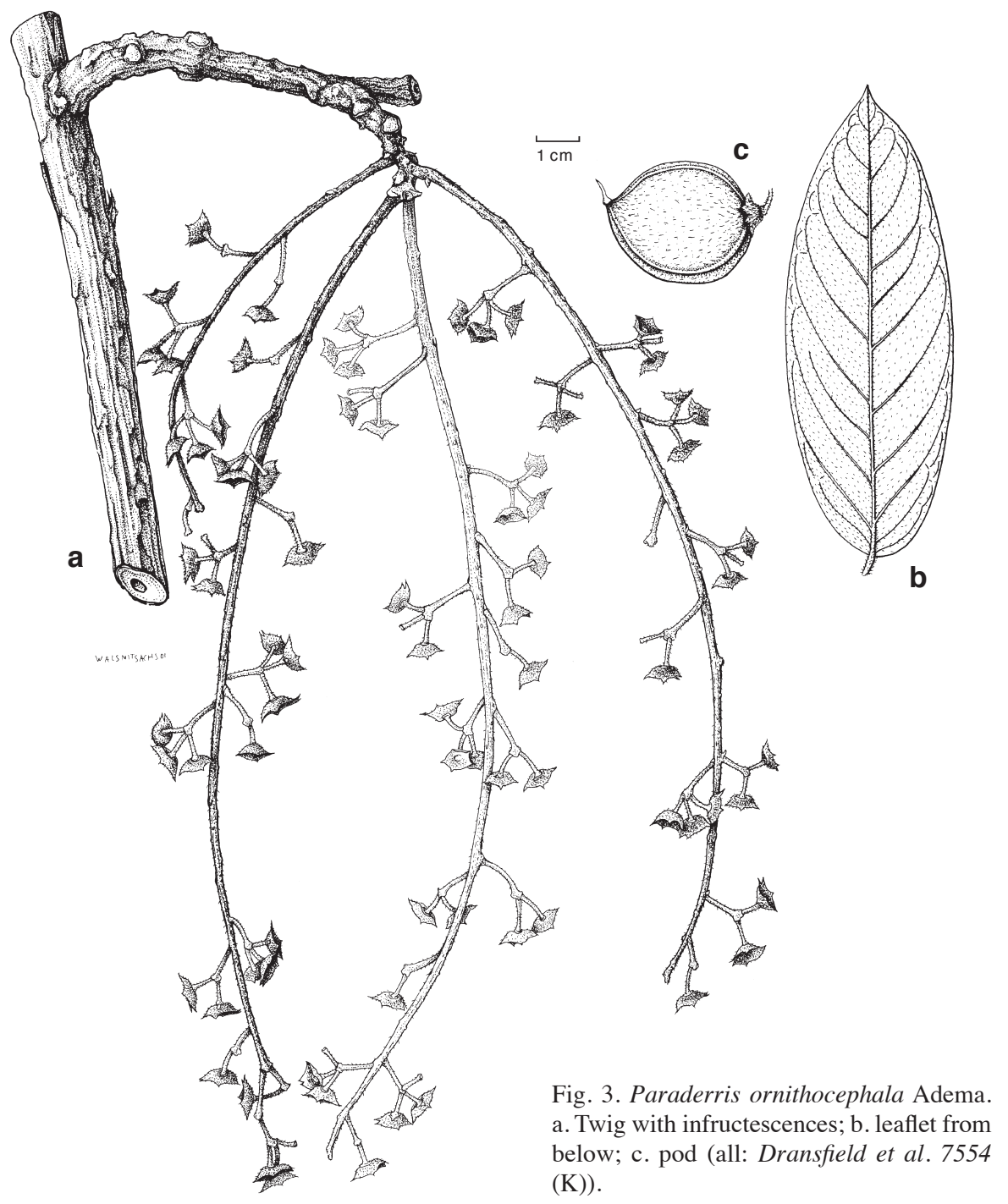

rounded or slightly cordate, apex acuminate, acumen 5-9 $\mathrm{mm}$ long, above glabrous, below thinly hirsute or sericeous (hairs often \pm patent), midrib slightly raised above, nerves \pm sunken above, $8-11$ per side, $4-15 \mathrm{~mm}$ apart, nervation reticulate-scalariform; lateral mostly as the terminal, elliptic to obovate, $6-13.5$ by $2.5-5 \mathrm{~cm}$, index $2.2-3.8$; pulvinus 5-8 mm long. Inflorescences (raminascent), pseudoracemes, $18-19 \mathrm{~cm}$ long, peduncle $4-6 \mathrm{~cm}$ long, thinly hirsute. Brachyblasts $5-15 \mathrm{~mm}$ long, 3-flowered at apex. Fruiting pedicels $7-8 \mathrm{~mm}$ long. Calyx in fruit c. $6.5 \mathrm{~mm}$ high, tube c. $5 \mathrm{~mm}$ high; vexillary lobe inconspicuous; lateral lobes triangular, c. 1.5 by $4 \mathrm{~mm}$; median lobe triangular, c. 2 by $5 \mathrm{~mm}$; outside sericeous, inside sericeous in upper part. Pods flattened discoid to 'oblong', $2.5-5.5$ by $2.5-3.5 \mathrm{~cm}$, outside \pm glaucous, thinly sericeous, upper wing 2-3 $\mathrm{mm}$ wide, lower wing $1 \mathrm{~mm}$ wide. 
Distribution - Papua Barat, Kepala Burung, Manokwari.

Habitat \& Ecology - Lowland forest along rivers on coral limestone. Fruiting: August.

Uses - Fish poison.

Note - Named 'ornithocephala' after the Bird's Head Peninsula (Kepala Burung or Vogelkop).

\section{KEY TO THE SPECIES IN MALESIA}

1a. Leaflets below glabrous to thinly strigose. Calyx outside glabrous, rarely with some hairs, ciliate at the margin of the lobes. Standard mostly glabrous or somewhat sericeous at apex. Pods glabrous or rather thinly sericeous. . . . . . . . 2

b. Leaflets below (thinly) sericeous or thinly strigose. Calyx outside sericeous. Standard sericeous except margin and claw. Pods (thinly) sericeous. . . . . . . . 3

2a. Pods winged along both sutures, upper wing $2-5 \mathrm{~mm}$ wide, lower wing $2-3 \mathrm{~mm}$

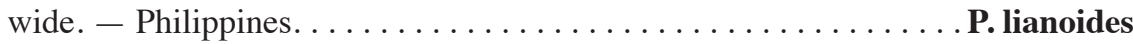

b. Pods not winged or winged along the upper suture only, rarely winged along both sutures, upper wing up to 2(-4) mm wide, lower wing up to $1(-2) \mathrm{mm}$ wide. - Throughout Malesia, except the Philippines; also cultivated . . . . P. montana

3a. Leaflets usually large and wide, terminal ones $4.5-16.5$ by $2-7 \mathrm{~cm}$. Bracts to the brachyblasts $1.9-3.5$ by $1.5-2.4 \mathrm{~mm}$, to the flowers $1.2-3.5$ by $1-1.9 \mathrm{~mm}$. Calyx

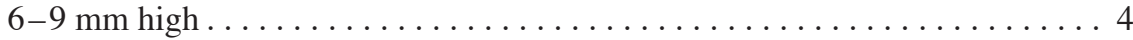

b. Leaflets usually smaller and narrower, terminal ones $2-7.5$ by $0.5-2 \mathrm{~cm}$. Bracts to the brachyblasts c. 0.9 by $0.8 \mathrm{~mm}$, to the flowers $0.8-0.9$ by $0.6 \mathrm{~mm}$. Calyx $4-6$ $\mathrm{mm}$ high. - Pods winged along both sutures, upper wing 2-6 $\mathrm{mm}$ wide, lower wing $1-3 \mathrm{~mm}$ wide $\ldots \ldots \ldots \ldots \ldots \ldots \ldots \ldots \ldots \ldots \ldots \ldots$. oblongifolia

4a. Pods winged along both sutures, upper wing $2-5 \mathrm{~mm}$ wide, lower wing (1-) $3-4$

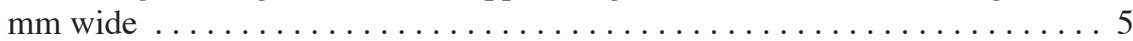

b. Pods winged along the upper suture only, wing 1.5-2.1 mm wide. - Throughout Malesia, in the Philippines only on Palawan; also cultivated . . . . . P. elliptica

5a. Leaves with 9-19 leaflets. Leaflets above almost glabrous to thinly sericeous (or hirsute). Pods broadly strap-like, $4.5-11$ by $1.5-4 \mathrm{~cm}$, not glaucous. - Philip-

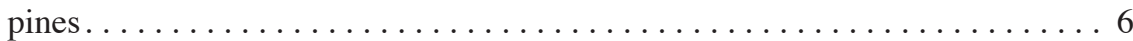

b. Leaves with 9 leaflets. Leaflets above glabrous. Pods discoid to oblong, 2.5-5.5

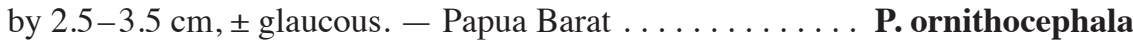

6a. Leaflets whitish-glaucous below. Inflorescences on short shoots . . P. luzoniensis

b. Leaflets not glaucous below. Inflorescences on short or long shoots . P. piscatoria

\section{ANNOTATED CHECKLIST}

\section{Paraderris (Miq.) Geesink}

Paraderris (Miq.) Geesink (1984) 109. - Derris Lour. sect. Paraderris Miq. (1855) 145; Benth. (1860) 111; Thoth. (1961) 190; Geesink (1981) 256; Thoth. (1982) 3. - Deguelia Aubl. sect. Paradeguelia Taub. (1894) 345, nom. illeg. - Lectotype (Geesink, 1984): Paraderris cuneifolia (Benth.) Geesink (= Derris cuneifolia Benth.). 
Paraderris canarensis (Dalzell) Adema, comb. nov.

Pongamia canarensis Dalzell (1850) 37. - Derris canarensis (Dalzell) Baker (1878) 246; Prain (1897) 347; Thoth. (1961) 190; (1982) 12. - Neotype (Thothathri, 1982): Ritchie 1720 (holo CAL), India, Kanara, Mysore, Kassaleh.

Derris oblonga Benth. (1860) 112. - Deguelia oblonga (Benth.) Taub. (1894) 245. - Syntypes: Stocks s.n., India, Concan; Gardener 476, Ceylon; Walker s.n., Ceylon; Thwaites 1493, Ceylon.

Clearly a Paraderris with leaflets quite different from those of other Paraderris species. The flowers are \pm similar to those of $P$. elliptica and $P$. montana, however, the indumentum of the calyx is more like that of P. cuneifolia.

\section{Paraderris cuneifolia (Benth.) Geesink}

Paraderris cuneifolia (Benth.) Geesink (1984) 109. - Derris cuneifolia Benth. (1852) 253; (1860) 112; Prain (1897) 459; Thoth. (1982) 13. - Deguelia cuneifolia (Benth.) Taub. (1894) 345. - Lectotype (Thothathri, 1982): Wallich Cat. 5887 (holo CAL; iso K (BM, LE n.v.)), Nepal, Nookate.

Galedupa marginata Roxb. [(1814) 53, nom. nud.]; (1832) 241. - Type: M.R. Smith s.n., India, Silhet (n.v.).

Derris discolor Benth. (1860) 111. - Type: J.D. Hooker s.n. (holo K; iso K), Sikkim, Terai, lower hills.

Derris hancei Hemsl. (1905) t. 8008 (after D. alborubra Hemsl.). - Type: Sampson s.n., China, Canton, along river (n.v.).

Derris glauca Merr. \& Chun (1935) 246. - Type: F.C. How 70860 (n.v.), China, Hainan, Ngai Yuen, 4.6.1933.

Derris truncata Craib (1927) 385. - Type: Kerr 8898 (holo K), Thailand, Pitsanaloh, Nakawn, Tai.

Derris cuneifolia Benth. var. longipedicellata Thoth. (1961) 191; (1982) 15. - Type: Ribu 760 (holo CAL), India, Sikkim, Sivoke.

Derris cuneifolia Benth. forma assamica Thoth. (1961) 192; (1982) 15. - Type: U. Kanjilal 4835 (holo CAL), Assam, Cachar, Bishnupur.

See discussion on p. 129, 131 .

\section{Paraderris elliptica (Wall.) Adema}

Paraderris elliptica (Wall.) Adema (2001) 11. - Pongamia elliptica Wall. (1832) 20,t. 237. - Derris elliptica (Wall.) Benth. (1860) 111; Prain (1897) 460; Thoth. (1961) 194. - Type: Wallich Cat. 5881 A (iso CAL, fragments), Hort. Bot. Calcutta (originally from Ambon).

Dalbergia purpurea Reinw. ex Hassk. (1842) 53. - Type: Blume s.n. (holo L, NHN-L 908.114987), Java.

Pongamia hypoleuca Miq. (1855) 148. - Lectotype (here designated): Korthals s.n. (holo L, NHN-L 908.114-986), Borneo.

Pongamia volubilis Zoll. \& Mor. var. glaucophylla Miq. (1855) 149. - Derris elliptica (Wall.) Benth. var. glaucophylla (Miq.) Kaneh. \& Hatus. (1942) 364. - Lectotype (here designated): Anonymous s.n. (holo L, NHN-L 908.114-971), Java.

See p. 133.

Paraderris elliptica (Wall.) Adema var. chittagongensis (Thoth.) Adema, comb. nov.

Derris elliptica (Wall.) Benth. var. chittagongensis Thoth. (1961) 195; (1982) 18. - Type: Baldal Khan $450(C)$ (holo CAL; iso CAL), India, Chittagong, Kodla, 30 mi from Chittagong. 
This variety is rather similar to Paraderris elliptica. It differs in the colour of the indumentum: golden in var. chittagongensis, whitish in var. elliptica; the young pods are rather large with distinct wings along both sutures (in var. elliptica with a wing along the upper suture only); the topmost part of the rachis (ultra jugal part) which is very short (in var. elliptica never very short). In several aspects also \pm similar to P. lacei and P. lushaiensis.

Paraderris hainanensis (Hayata) Adema, comb. nov.

Derris hainanensis Hayata (1913) 77. - Type: K. Katsumada s.n.(n.v.), Hainan, 1911.

Rather similar to $P$. cuneifolia, from which it differs in its narrower leaflets, larger flowers, and slightly narrower pods.

Paraderris lacei (Dunn) Adema, comb. nov.

Derris lacei Dunn (1914) 208. - Lectotype (here designated): Lace 6115 (holo K; iso CAL), Burma, Maymyo Plateau, 12.3.1913.

Related to P. elliptica. Paraderris lacei is characterized by its short brachyblasts and very large flowers. The only specimen seen has young leaves only. According to the field notes on the label in full flower before the foliage appears.

Paraderris laotica (Gagnep.) Adema, comb. nov.

Derris laotica Gagnep. (1911) 348. - Type: Magnen, Gourgand \& Châtillon s.n. (lectoholo (Phan Kê Lôc \& Vidal, 2001); iso K, fragments), Cambodia, Bhâklon.

Derris laotica Gagnep. var. virens Gagnep. (1911) 348. - Lectotype (Phan Kê Lôc \& Vidal, 2001): Godefroi 686 (holo P), Cambodia, Sien-reap.

In indumentum of calyx and corolla similar to P. cuneifolia. Paraderris laotica differs from the latter in its trifoliolate leaves, larger flowers and pods with much wider wings.

Paraderris lianoides (Elmer) Adema, comb. nov.

Derris lianoides Elmer (1907) 228. - Type: Elmer 7443 (holo PNH?; iso CAL, K), Philippines, Luzon, Prov. Taybas, Luchon.

See p. 129, 131.

Paraderris lushainensis (Thoth.) Adema, comb. nov.

Derris lushainensis Thoth. (1972) 104; (1982) 21. - Type: Gage 23D (A) (holo CAL), India.

Probably closely related to $P$. lacei. The species is characterized by its large flowers and the very short topmost rachis part (ultrajugal part). In the latter aspect it is similar to P. elliptica var. chittagongensis.

\section{Paraderris luzoniensis Adema}

See p. 134. 
Paraderris montana (Benth.) Adema, comb. nov.

Derris montana Benth. (1852) 253; (1860) 113. - Type: Junghuhn s.n. (BO? n.v.), Java, Dieng.

Derris cuneifolia Benth. var. malaccensis Benth. (1860) 112. - Derris malaccensis (Benth.) Prain (1897) 107. - Paraderris malaccensis (Benth.) Adema (2001) 11. - Type: Griffith 1774 (holo $\mathrm{K}$; iso CAL), Malaysia, Malacca.

Derris malaccensis (Benth.) Prain var. aptera Prain (1897) 108. - Lectotype (here designated): King's coll. 4518 (holo K; iso A, CAL), Malaysia, Perak.

Derris malaccensis (Benth.) Prain var. millettioides Prain (1897) 108. - Type: King's coll. 10696 (iso CAL), Malaysia, Perak, 8.1886.

Derris pachycarpa Merr. (1922) 310. - Type: BS 1250 (Ramos) (iso K), Borneo, Sabah, Batu Lima, near Sandakan.

Derris caudata Backer (1945) 513. - Type: Backer 7061 (BO?, L), Java, Bantam, Menés, on riverbank.

Derris danauensis Backer (1945) 513. - Type: Van Steenis 10539 (BO?, L), Java, Rawah Danau, on hoema's,11.8.1937.

Some time after I transferred Derris malaccensis to Paraderris, I discovered that Derris montana and D. malaccensis are synonymous. However, it was impossible to correct the statement in the paper in Thai. For. Bull. where I created the combination P. malaccensis (Adema, 2001). The correct name and more complete synonymy are given above. See also p. 129, 131.

Paraderris oblongifolia (Merr.) Adema, comb. nov.

Derris oblongifolia Merr. (1912) 82. - Type: Vanoverberg 280 (n.v.), Philippines, Luzon, Subprov. Bauco, Bontoc.

See p. 133.

\section{Paraderris ornithocephala Adema}

See p. $133,134$.

\section{Paraderris piscatoria (Blanco) Adema}

Cyclista piscatoria Blanco (1837) 589. - Millettia piscatoria (Blanco) Merr. (1905) 37. - Neotype (here designated): Merrill Spec. Blanc. 469 (holo L; iso A, K), Philippines, Luzon, Batangas Prov., Mt Batulo.

See p. 133.

\section{DUBIOUS SPECIES}

1. Derris acuminata Benth. (1852) 252; (1860) 109; Thoth. (1961) 200; (1982) 5. - Lectotype (Thothathri, 1982): Wallich Cat. 5901 (holo K; iso LE n.v.).

Derris microptera Benth. (1860) 113; Thoth. (1961) 194. - Type: Hookerf. s.n. (holo K n.v.), India, Sikkim, 1852.

Derris microptera Benth. var. sikkimensis Thoth. (1976) 143; (1982) 7. - Type: Hooker f. s.n. (holo K n.v.), India, Sikkim, 1852.

According to Bentham (1860) the species belongs to Derris sect. Euderris (= Derris), according to Thothathri $(1961,1982)$ to Derris sect. Paraderris. Prain (1897) synonymized the species with Derris cuneifolia (= Paraderris cuneifolia). Derris 
acuminata probably belongs to Paraderris, however, the brachyblasts are very short. In some aspects of the leaflets it is similar to Paraderris canarensis.

2. Derris macrocarpa Thoth. (1961) 192; (1982) 22. - Type: Sri Ram 2667 (holo DD; iso DD n.v.), India, Uttar Pradesh, Bahraich distr, Nishangaru.

From the description it is probably a Paraderris species. It should be compared with other species with large two-winged fruits.

\section{NOTES ON SPECIMENS}

\section{Thailand}

1. BKF 14184, BKF 26317, Van Beusekom \& Phengklai 1027, Thailand, SW, Kanchanburi.

Related to Paraderris elliptica. These specimens may represent a new species.

2. K. \& S. Larsen 33394, Thailand, Peninsular, 30-70 km S of Ranong, transition between deciduous and evergreen forest, alt. 60-200 m, 11.06.1974.

This specimen has an uncommon combination of characters: trifoliate leaves and very large terminal pseudopanicles. Its brachyblasts are Paraderris-like.

3. K. \& S. Larsen, S.S. Renner \& C. Niyomdham 43031, Thailand, Prov. Yaha, Ban Niangok Yaha, alt. 50-75 m, 11.06.1992.

This specimen probably belongs to the group of Paraderris elliptica. It has a Paraderris inflorescence and a calyx that is sericeous on the outside. However, the pods of this specimen are more Derris-like.

\section{Malesia}

4. De Vogel 5251, Celebes, Sopa Valley, c. $80 \mathrm{~km}$ SSE of Palu.

This specimen seems closely related to Paraderris montana. The calyx below the young fruits is slightly more hairy than is usual for P. montana. At present included in P. montana.

5. S. Prawiratmodjo \& S. Soewoko 1842 , Celebes, $105 \mathrm{~km} \mathrm{~S}$ of Polipoli, around Opa Swamp, alt. 20-200 m.

This large liana has Derris scandens-like leaves. The inflorescences are partly Paraderris pseudoracemes, partly panicles. The pods are two-winged with a rather wide upper wing and much narrower lower wing. The calyx of the specimen is similar to that of P. montana. The specimen may represent a new species.

\section{ACKNOWLEDGEMENTS}

The loan of material from the herbaria: A, AAU, CAL, K, L, LAE, MO, PNH, SING, U is gratefully acknowledged. The Keeper of the herbarium and the members of the Leguminosae group at the Royal Botanic Gardens, Kew are thanked for their hospitality and help during my visit to Kew. Jan Frits Veldkamp kindly translated the diagnoses of the new species into Latin. Anita Walsmit-Sachs made the beautiful drawings. 


\section{REFERENCES}

Adema, F. 2001 ('2000'). Notes on Malesian Fabaceae XX. Derris in Thailand and Malesia. Thai. For. Bull., Bot. 28: 2-16.

Backer, C.A. 1945. Notes on the Flora of Java, II. Blumea 5: 490-524.

Backer, C.A. \& R.C. Bakhuizen van de Brink Jr. 1964. Flora of Java 1. Noordhoff, Groningen.

Baker, J.G. 1878. In: H.D. Hooker, Flora of British India. Vol. 2. Reeve \& Co, Brook nr. Ashford, Kent, United Kingdom.

Bentham, G. 1852. In: F.A.W. Miquel, Plantae Junghuhniae. Sythoff, Leiden.

Bentham, G. 1860. Synopsis of Dalbergieae, a tribe of Leguminosae. Proc. Linn. Soc. 4, Suppl.: $1-134$.

Blanco, M. 1837. Flora de Filipinas. Candido Lopez, Manila.

Craib, W.G. 1927. In: Anonymous, Contributions to the Flora of Siam. Additamentum 23. Kew Bull. 1927: 374-395.

Dalzell, N.A. 1850. Contributions to the botany of Western India. Hooker's J. Bot. 2: 33-41.

Dunn, S.T. 1914. In: Anonymous, Decades Kewenses. Plantarum Novarum in Horti Regii Conservatum. Decas 80. Kew Bull. 1914: 205-210.

Elmer, A.D.E. 1907. Some new Leguminosae. Leafl. Philipp. Bot. 1: 220-232.

Gagnepain, F. 1911. Classification des Derris d'Extrême-Orient et descriptions d'espèces nouvelles. Not. Syst. 2: 341-350.

Geesink, R. 1981. Tribe 6. Tephrosieae (Benth.) Hutch. (1964). In: R.M. Polhill \& P.H. Raven, Advances in Legume systematics. Part 1. Royal Botanic Gardens, Kew.

Geesink, R. 1984. Scala Millettiearum. Leiden Bot. Ser. 8.

Hasskarl, J.K. 1842. Plantarum genera et species novae aut reformatae javenses. Flora 25, Beibl. II: $1-56$.

Hayata, B. 1913. Icones Plantarum Formosanarum 3. Govt. of Formosa, Taikohu.

Hemsley, W.B. 1905. Tab. 8008. Derris alborubra. Bot. Mag. 131: t. 8008.

Kanehira, R. \& S. Hatusima. 1942. The Kanehira-Hatusima 1940 collections of New Guinea plants. 12. Leguminosae. Bot. Mag. Tokyo 56: 355-371.

Merrill, E.D. 1905. A review of the identifications of the species described in Blanco's Flora de Filipinas. Bur. Govt. Lab. Publ. 27: 1-132.

Merrill, E.D. 1912. Sertulum Bontocense. Philipp. J. Sci., Bot. 7: 71-107.

Merrill, E.D. 1922. New and noteworthy Bornean plants. J. Straits Branch Roy. Asiat. Soc. 86: $310-342$.

Merrill, E.D. \& W.Y. Chun. 1935. Additions to our knowledge of the Hainan flora II. Sunyatsenia 2: $203-333$.

Miquel, F.A.W. 1855. Flora Indiae Batavae 1. Van der Post, Amsterdam, Utrecht.

Phan Kê Lôc \& J.E. Vidal. 2001. Flore du Cambodge, du Laos et du Viêtnam. 30. LeguminosaeMillettieae. Muséum National d'Histoire Naturelle, Paris.

Prain, D. 1897. Noviciae Indicae XV. Some additional Leguminosae. J. Asiat. Soc. Bengal 66, 2: 347-518.

Roxburgh, W. 1814. Hortus Bengalensis. Serampore.

Roxburgh, W. 1832. Flora Indica. Vol. 3. Thacker \& Co., Calcutta \& Parbury, Allen \& Co., London.

Taubert, P. 1894. Leguminosae. In: A. Engler \& K. Prantl, Die Natürlichen Pflanzenfamilien 3, 3: $70-388$.

Thothathri, K. 1961. Studies in Leguminosae 1. A taxonomic revision of the genus Derris Lour. in India. Bull. Bot. Surv. India 3: 175-200.

Thothathri, K. 1972 ('1970’). Studies in Leguminosae 14. Further contributions to the genus Derris Lour. from India. Bull. Bot. Surv. Ind. 12: 104-107.

Thothathri, K. 1976. Studies in Leguminosae 24. Notes on the Indo-Burmese species of Derris. J. Jap. Bot. 51: 141-150.

Thothathri, K. 1982. Leguminosae: Genus Derris. Fasc. Fl. India 8: 1-33.

Wallich, N. 1832. Plantae Asiaticae Rariores 3. Treuttel \& Würtz, London. 


\section{IDENTIFICATION LIST}

\author{
Paraderris \\ 1. P. cuneifolia \\ 2. P. elliptica \\ 3. P. lianoides \\ 4. P. luzoniensis
}

\author{
5. P. montana \\ 6. P. oblongifolia \\ 7. P. ornithocephala \\ 8. P. piscatoria \\ 9. P. spec.
}

Alston 15365: 2 - Ambri, Arifin \& Arbainsyah AA 1412: 5 - Ambri et al. AA 1620: 2 - Ambriansyah \& Arifin AA 243: 5 - Anderson 5149: 2 - Axelius 329: 5.

Backer 4359: 5; 7061: 5; 34065: 2 - bb 14497: 2; 14501: 2; 24549: 2 - Beccari 3761: 5 - Beumée 683: 2 - Bicknell 814: 8 - Bish 74: 2 - BKF 17907: 5; 31899: 5 - Blume 1503: 5 - BNBFD A1319 (Cuadra): 2; A2440 (Cuadra) 2; A2809 (Kadir): 5; 2328 (Calacala): 2; 2445 (Melegrito): 2; 2744 (Telado): 2; 3144 (Puasa): 5; 8876 (King): 2 - Boerlage 238: 2 - Bourell 2366: 2 - Branderhorst 222: 2 - Brass 1100: 5; 24256: 2 - Brooke 8827: 5 - Brun 5142 (Ashton): 2 - BS 280 (Vanoverbergh): 6; 455: 5; 1066 (Ramos): 8; 1193 (McGregor): 6; 1250 (Ramos): 5; 4570 (Ramos): 8; 9225 (Merrill): 3; 11093 (Ramos): 8; 14500 (Ramos): 8; 17640 (Ramos): 3; 18645 (McGregor): 8; 20470 (Ramos): 8; 22487 (Ramos \& Deroy): 8; 29540 (Ramos \& Edaño): 8; 33043 (Ramos): 3; 33160: 6; 37062 (Ramos \& Edaño): 3; 45185 (Ramos \& Edaño): 3; 46800 (Ramos \& Edaño): 6; 76803 (Ramos) 6; 79942 (Ramos): 6; 85036 (Ramos \& Edaño): 8.

Caniocosa 420: 8 - Christensen 1192: 2; 1375: 2 - Christensen \& Apu 303: 2; 393: 2 - Chin See Chung 2763: 5 - Clarke 17266: 1 - Clemens 537: 3 - Coode, Ridsdale \& Reynoso 5483: 8 - Coode et al. 6436: 5 - Curtis 1160: 2; 1438: 2; 2735: 5; 2735A: 5; 2953: 2.

Danser 5860: 2; 5860A: 2 - De Vogel 5251: 5 - De Voogd 155: 2; 793: 2 - De Wilde \& De WildeDuyfjes 12601: 5; 13572: 5; 13949: 5; 19243: 5; $21227: 5$ - Dec. Phil. For. fl. 178 (Ahern's coll.): 6 - Dorgelo 988: 2; 2183: 2 - Dornstreich 9: 2; 10: 5; 59: 2; 118: 5 - Dransfield et al. 7554: 7.

Ebalo 645: 2; 1136: 8 - Elmer 5864: 6; 7443: 3; 8172: 8; 9339: 3; 10095: 8; 11075: 6; 11989A: 6; 15528: 6; 17708: 8 - Endert 1452: 2; 3038: 5 - Eyma 1587: 2.

FB 1164 (Ahern's coll.): 8; 2681 (Ahern's coll.): 3 - FMS FD 11166 (Strugnell): 5; 16917 (Hamid): 2; 37804 (Symington): 2 - Forbes 1623: 2 - FRI 4937 (Whitmore): 2; 11246 (Chan): 5.

Garrett 160: 2 - Gianno 317: 5; 331: 2 - Griffith 1769: 2; 1774: 5 - Groff 6141: 2.

Hallier 474: 2; 624: 2; 1107: 5 - Hardial \& Samsuri 265: 5 - Hartley 10185: 5 - Hassan \& Nurta 120: 2 - Haviland 535: 5; 2891: 5; 2900: 5 - Herb. Boschproefstat. 4486: 5 - Horsfield L21: 2 - How 70860: 1 .

Jacobs 8004: 6 - Janowski 191: 2; 444: 5; 453: 2 - Junghuhn 20: 5; 212: 2.

Kadim \& Mahmood 48: 5 - Upendranath Kanjilal 4835: 1. - Keith 271: 2 - Kerr 2531: 2; 5122: 2 ; 5835: 2 ; 7705: $2 ; 8893: 2 ; 8898: 1 ; 10325: 2 ; 10623: 2 ; 14963: 5 ; 17228: 5 ; 18127: 2$ - Keßler et al. PK 1684: 2 - King's coll. 1431: 2; 4028: 5; 4149: 5; 4504: 5; 4518: 5; 5428: 5; 8337: 5; 8531: 5; 10696: 5 - KL 1613 (Gadoh anak Umbai): 5; 2115 (Gadoh anak Umbai): 5 - Koorders 21286: 2; 29284: 2; 40930: 2 - Kornassi 495: 2 - Kostermans Kwai Nei River Exped. 260: 2; Kwai Nei River Exped. 791: 5; 4656: 5; 19337: 2; 212356: 5 - Krukoff 4459: 5 - Kuntze 5564: 2.

LAE 70237 (Wiakabu \& Kairo): 5; 70799 (Katik): 5 - Lei 612: 1- Loher 2253: 8; 2254: 8; 2255: 8; 2256: 8 - Lörzing 11753: 5 - Luoma 3: 2.

Maingay 554 (1636): 2; 556: 2; 613 (2585?): 5; 4149 (1623A, B): 2 - Masters 75: 1 - Maxwell 85-283: 5; 86-140: 5; 86-445: 5; 87-448: 5; 88-467: 2; 89-466: 2 - Merrill 4043: 8; 9225: 3; 9347: 3; 9473: 8; 9485: 8; Spec. Blanc. 469: 8 - Motley 769: 2.

NGF 3903 (Womersley): 5; 11574 (Henty): 2; 20077 (Van Royen): 5; 20974 (Henty): 5; 21735 (Sayers): 5; 46495 (Womersley): 5.

Paijmans 439: 5 - Pearson 85: 2 - PNH 4614 (Alcasio \& Edaño): 3; 4684 (Fox): 8; 6381 (Sulit): 3; 10656 (Mendoza \& Convocar): 8; 12258 (Cachalian): 8; 14316 (Sulit): 3; 14372 (Sulit): 3; 14411 (Sulit): 8; 17658 (Sulit \& Conklin): 8; 18970 (Sulit \& Conklin): 8; 19312 (Conklin): 8; 19313 (Conklin): 8; 19314 (Conklin): 8; 19315 (Conklin): 8; 19316 (Conklin): 8; 19317 (Conklin): 8; 
21559 (Sulit): 6; 21616 (Sulit): 6; 37909 (Conklin): 8; 37940 (Conklin): 8; 38131 (Frake): 6; 39244 (Conklin): 3; 78649 (Conklin \& Buoaya): 6; 159931 (Aragon): 8 - Polak 519: 2 - Posthumus 818: 2 - Powell 420: 2 - PPI 20163 (Argent c.s.): 6 - Prawiroatmodjo \& Soewoko 1842: 9. Rahmat si Boeea 1202: 5 - Reeve 5309: 2 - RFD 17801: 2 - Ribu 760: 1 - Ridley 1227a: 2; 10796: 5; 15592: 5; 16325: 5 - Ridsdale et al. ISU 564: 4 - Rogstad 791: 2 - Rutten 122: 2; 739: $2 ; 772: 2$.

S 14074 (Smythies): 5; 45233 (Chai \& Ismawi): 2; 54326 (Ismawi): 5; 58020 (Kandau Jenang): 2; 67316 (Rentao Jawa et al.): 5; 67439 (Runi et al.): 2 - SAN 30029 (Aban Gibot): 5; 53111 (Madani): 5; 77211 (Shea \& Aban): 5; 83200 (Saikeh Lantoh): 5; 95526 (Amin): 5; 113923 (Sumbing Jimpin): 5; 115719 (George et al.): 5; 116767 (Mansus et al.): 5; 121505 (Amin et al.): 5; 122224 (Mansus \& Amin): 5 - Sands, Pattison \& Wood 1406: 2 - Santos 5238: 8 - Schmutz 4706: 2; 4736: 2 - Schuitemaker 143: 2; 145: 2; 156: 2; 157: 2; 159: 2; 160: 5; 162: 2; 163: 2 - Scortechini 1738a: 2 - SF 14738 (Boden Kloss): 2; 14836 (Haniff): 2; 15592: 5; 17166 (Burkill \& Haniff): $5 ; 28638$ (Corner): 5 - Shah \& Noor 2044: 2 - SMHI 85 (Ridsdale et al.): 3; 293 (Ridsdale): 3; 703 (Podzorski): 8; 1863 (Ridsdale): 3 - Soejarto \& Madulid 6096: 3 - Soejatmi Soenarko 365: 5 - Sriboonma 1: 2 - Stone et al. 15190: 2 - Surbeck 100: 2.

Van Niel 3721: 2; 4638: 5 - Van Ooststroom 13678: 2; 13696: 2 - Van Steenis 10539: 5 - Vanoverbergh 3904: 6 - Varadarajan et al. 1570: 6 - Versteeg 1823: 2 - Vidal 257: 8; 1083: 8; 1242bis: $8 ; 1280$ : 8; 2580: 8; 2592: 8; 2597: 3; 2603: 8; 2634: 8; 2665: 3 .

Wallich Cat. 5881A: 2; 5887: 1; 5896: 1; 5897: 1 - Waterhouse, Rakunat \& Nodup ser 32062 coll. 413: 2 - Wenzel 1899: 3 - Whitford 60: 8 - Williams 2788: 6 - Wray 1678: 2; 1678A: 2; 2025: 5 .

Zollinger 325: 2 .

\section{INDEX OF NAMES}

The accepted names are in roman type, the synonyms and dubious species in italics and the new names in bold.

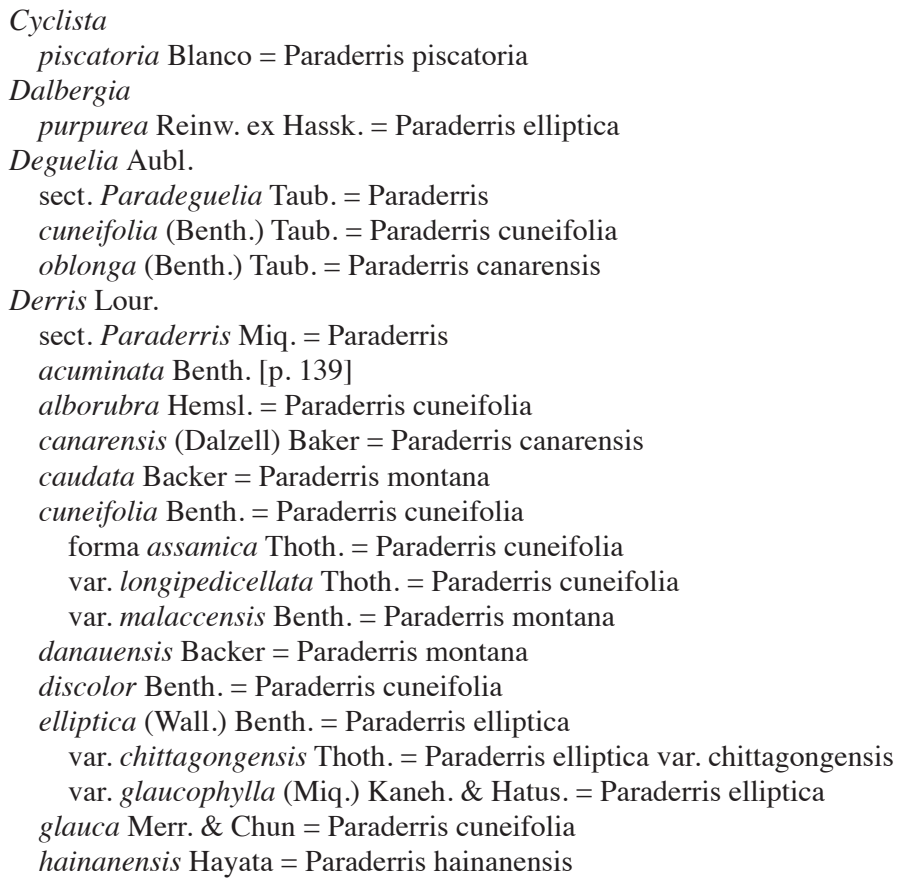




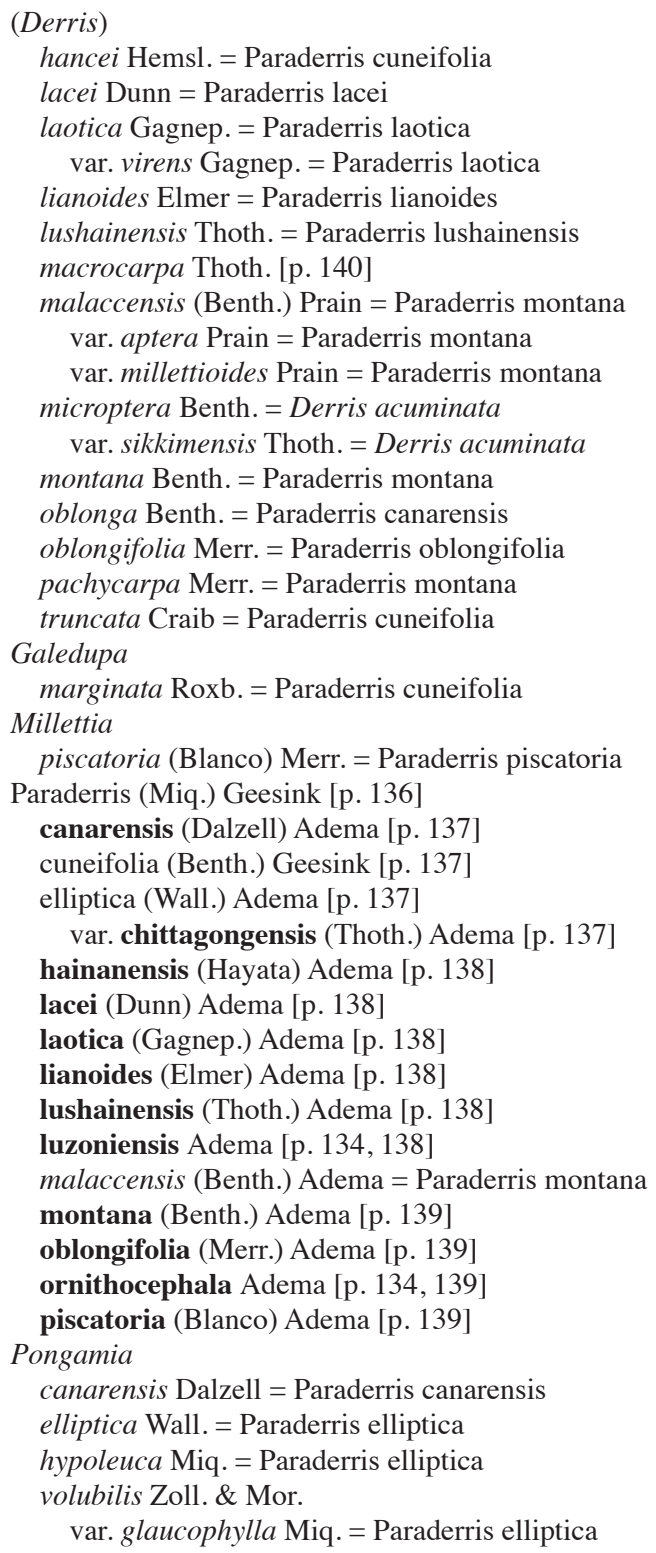

